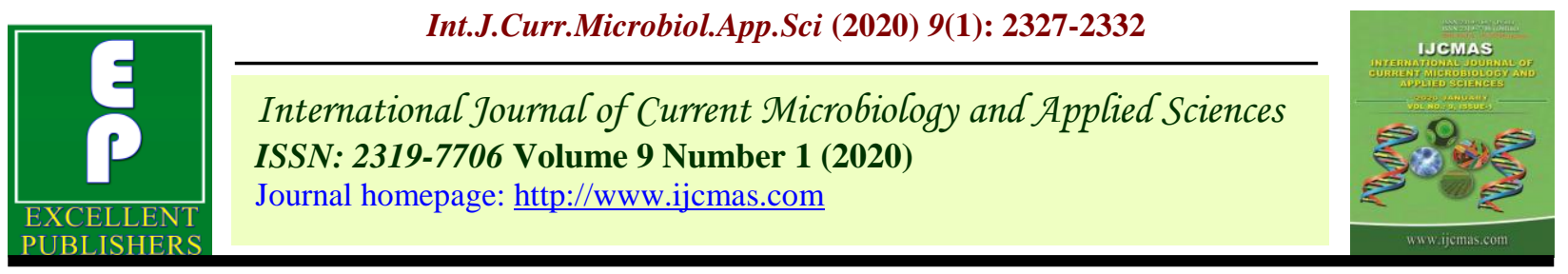

Original Research Article

https://doi.org/10.20546/ijcmas.2020.901.264

\title{
Long Term Effect of Organic, Integrated and Inorganic Nutrient Management Practices on Crop Performance and Quality Parameters of Rice (Oryza sativa L.) in a Vertisol
}

\author{
Praveen Karikatti $^{1}$, S. N. Bhat $^{1 *}$, S. R. Balanagoudar ${ }^{1}$, B. G. Mastanareddy ${ }^{2}$, \\ Satyanarayana $\operatorname{Rao}^{2}$ and $H$. Veeresh ${ }^{1}$ \\ ${ }^{1}$ Department of Soil Science and Agril. Chemistry, ${ }^{2}$ Department of Agronomy, \\ University of Agricultural Sciences, Raichur- 584 104(Karnataka), India \\ *Corresponding author
}

\begin{tabular}{|l|}
\hline K e y w o r d s \\
Organics, \\
$\begin{array}{l}\text { Inorganics, Long } \\
\text { term effect, Paddy }\end{array}$ \\
\hline Article Info \\
\hline $\begin{array}{l}\text { Accepted: } \\
22 \text { December } 2019 \\
\text { Available Online: } \\
\text { 20 January } 2020\end{array}$ \\
\hline
\end{tabular}

A B S T R A C T

A field experiment on paddy ( var-BPT-5204) was conducted for eleven years (2005-06 to 2016-17) on a deep black clayey vertisol at Agricultural Research Station, Gangavati, UAS, Raichur to compare the influence of organic and conventional farming systems on productivity and grain quality parameters of rice with the following treatments viz., $\mathrm{T}_{1}: 100 \% \mathrm{~N}$ through organics, $\mathrm{T}_{2}: 75 \% \mathrm{~N}$ through organics, $\mathrm{T}_{3}$ : Integrated $\mathrm{N}$ management $(50 \% \mathrm{~N}$ through organics $\& 50 \%$ $\mathrm{N}$ through organics), $\mathrm{T}_{4}: 100 \% \mathrm{~N}$ through in-organics along with FYM @ $7 \mathrm{t} / \mathrm{ha}$, $\mathrm{T}_{5}: 100 \%$ RDF (150: $75: 75 \mathrm{~kg} / \mathrm{ha}$ ). The experiment was laid out in a Randomized Block Design and treatments were replicated four times. The observation pertaining to crop performance and quality parameters were recorded. Results revealed that yield attributing characters viz., number of panicle, seed count and 10 panicle weight and grain yield were significantly higher due to application 100 per cent $\mathrm{N}$ through organics compared to other treatments. The physical, cooking and nutritional quality of rice was remained to be non -significant among the treatments due to application of organic, in-organic and their integration. But there was significant difference in Head Rice Recovery (Physical quality) due to application of $100 \% \mathrm{~N}$ through organics and also $\mathrm{P}$ and $\mathrm{K}$ (nutritional quality) compared to application of $100 \% \mathrm{~N}$ through in-organics.

\section{Introduction}

In recent years, chemical fertilizer have played significant role in providing nutrients for in providing nutrients for intensive crop production. But long-term use of chemical fertilizer in unbalanced manner has created problems of multiple nutrient deficiencies, diminishing soil fertility and un-sustainable crop yields. As our dependence on the chemical fertilizer is in-escapable, we have to devise systems where we can prolong the period of their use as for as possible. Thus, for sustainable agriculture, the renewable and 
recyclable nutrient sources need to be integrated with chemical fertilizer in a manner that the high production systems of intensive agriculture are not only further improved but our soil as nature resource is also properly conserved. Keeping this in view, long-term field experiment on rice-rice system was conducted on a fixed location since 2005-06 at Agriculture Research Station, Gangavathi, to know the impact of repeated application of organic sources with or without chemical fertilizers on crop performance and quality of paddy. The information on long term effect of organic, integrated and inorganic nutrient management practises on yield attributes, yield and quality of paddy is lacking, observations were recorded during 2016-17 from the long term experiment.

\section{Materials and Methods}

The present investigation entitled "Long term effect of organic, in-organic and integrated nutrient management practices on yield and quality parameters of paddy (var. BPT-5204) in a Vertisol of TBP command area" is being carried out since 2005-06 on a fixed location during Kharif season at ARS, Gangavathi, UAS, Raichur ( Northern Dry Zone-Zone 3) of Karnataka state. Experiment consisted of 5 treatments, which were replicated four times and laid out in RCBD design. The treatments were: $\mathrm{T}_{1}: 100 \% \mathrm{~N}$ through organics, $\mathrm{T}_{2}: 75 \%$ $\mathrm{N}$ through organics, $\mathrm{T}_{3}$ : Integrated $\mathrm{N}$ management $(50 \% \mathrm{~N}$ through organics \& 50 $\% \mathrm{~N}$ through organics), $\mathrm{T}_{4}: 100 \% \mathrm{~N}$ through in-organics along with FYM @ 7 t/ha, $\mathrm{T}_{5}: 100$ $\%$ RDF (150: 75:75 kg/ha). The experimental soil characteristics were: slightly alkaline $(\mathrm{pH}$ 8.1); non-saline (EC $0.45 \mathrm{dS} / \mathrm{m}$ ); and medium soil organic carbon $(0.65 \%)$ content. Soil available $\mathrm{N}$ was low (220 kg/ha); available phosphorus was medium (45.0 kg P2O5/ha); available potassium was high $(650 \mathrm{~kg} \mathrm{~K} 2 \mathrm{O}$ /ha) .The organic sources used were: crop residue, FYM, neem cake and poultry manure. The recommended dose of inorganic fertilizers were given at the rate of 150:75:75 $\mathrm{kg} \mathrm{N}, \mathrm{P}_{2} \mathrm{O}_{5}, \mathrm{~K}_{2} \mathrm{O} / \mathrm{ha}$ and $25 \mathrm{~kg} \mathrm{ZnSO}_{4} / \mathrm{ha}$ were applied. Nitrogen was given in three equal splits at basal, maximum tillering and panicle initiation stages, while $\mathrm{P}, \mathrm{K}$ and $\mathrm{Zn}$ were given as basal doses only. Through organics ( crop residues, FYM, poultry manure \& neem cake), $\mathrm{N}$ dose was adjusted to recommended level based on their moisture content and ' $\mathrm{N}$ ' concentration on dry weight basis. Recommended cultural practises were followed .Yield and quality parameters of rice were recorded as per the standard procedures.

\section{Yield parameters}

\section{Number of panicle /sq.mt.}

Number of panicle/sq.mts was significantly influenced by treatments (table $1 \&$ fig.1). Treatment receiving $100 \%$ nitrogen through organics recorded the higher panicle/sq.mts (T1:376) and the least number of panicle/sq.mts was recorded in the treatment that receiving recommended dose of chemical fertilizer (T5:293). The reason attributed for higher number of panicle/sq.mts might be due improvement in physical condition of soil with addition of organics, better availability of nutrients in soil and absorption of nutrients in the treatment which received organic sources. Similar findings were also reported by Hemalatha et al., (2000) and Shukla et al., (2016).

\section{Panicle weight and seed count per panicle}

Individual panicle weight is important from final yield point of view. Supply of nutrients through organic source recorded significantly more panicle weight and seed count (4.03 g \& 256 , respectively) than that through chemical fertilizers (3.03 g \& 192) (Table $1 \&$ fig.1 ). This may be due to more number of filled grains per panicle and lengthy panicles 
produced, which intern resulted in higher panicle weight. These results are in conformity with the findings of Dwivedi and Thakur (2000) and Hemalatha et al., (2000).

\section{Grain yield}

Significantly higher grain yield of $55.93 \mathrm{q} / \mathrm{ha}$ was recorded in the treatment which received $100 \%$ nitrogen through organic source (table $1 \&$ fig.1) followed by $75 \%$ nitrogen supplement through organics (50.93q/ha) and integration of both organic and inorganic source $(48.31 \mathrm{q} / \mathrm{ha})$. The higher yield recorded is due to improved physical condition of soil, better availability of plant nutrients throughout growth period, higher microbial population and their activity as supported by data presented in previous tables, which reflected in realizing more number of panicle/sq.mts and higher yield in these treatments. It is in line with findings of Thiagarajan (1991) and Gopalasamy and Vidhyasekaran (1987).

Table.1

Table.1 Yield parameters and yield of paddy as influenced by different treatments (after 11 years)

\begin{tabular}{|c|c|c|c|c|}
\hline Treatment & $\begin{array}{l}\text { No. of panicle } \\
\text { (per sq.m.) }\end{array}$ & $\begin{array}{c}\text { Seed } \\
\text { count/panicl } \\
\text { e }\end{array}$ & $\begin{array}{c}10 \text { Panicle } \\
\text { weight } \\
\text { (g) }\end{array}$ & $\begin{array}{l}\text { Grain yield } \\
\left(\mathbf{q} \mathbf{h a}^{-1}\right)\end{array}$ \\
\hline $\mathrm{T}_{1}: 100 \% \mathrm{~N}$ through organics & 376 & 256 & 4.03 & 55.93 \\
\hline $\mathrm{T}_{2}: 75 \% \mathrm{~N}$ through organics & 331 & 233 & 3.67 & 50.93 \\
\hline $\begin{array}{l}\mathrm{T}_{3}: 50 \% \mathrm{~N} \text { through organics \& } 50 \\
\% \mathrm{~N} \text { through inorganic }\end{array}$ & 358 & 219 & 3.50 & 48.31 \\
\hline $\begin{array}{l}\mathrm{T}_{4}: 100 \% \mathrm{~N} \text { through in-organics } \\
\text { and FYM @ } 7 \mathrm{t} / \mathrm{ha}\end{array}$ & 363 & 186 & 2.94 & 39.25 \\
\hline$T_{5}: 100 \%$ RDF, $150: 75: 75 \mathrm{~kg} / \mathrm{ha}$ & 293 & 192 & 3.03 & 40.25 \\
\hline $\mathrm{SEm} \pm$ & 8.36 & 11.84 & 0.13 & 0.98 \\
\hline CD@5\% & 25.76 & 36.50 & 0.42 & 3.03 \\
\hline
\end{tabular}

Table.2 Physical quality parameters of paddy grains as influenced by different treatments (after 11 years)

\begin{tabular}{|c|c|c|c|c|}
\hline Treatment & $\begin{array}{c}\text { Hulling } \\
(\%)\end{array}$ & $\begin{array}{c}\text { Milling } \\
(\%)\end{array}$ & $\begin{array}{c}\text { Head Rice } \\
\text { Recovery } \\
(\%)\end{array}$ & L/B ratio \\
\hline $\mathrm{T}_{1}: 100 \% \mathrm{~N}$ through organics & 77.3 & 68.8 & 53.6 & 2.81 \\
\hline$T_{2}: 75 \% \mathrm{~N}$ through organics & 77.2 & 68.3 & 50.7 & 2.84 \\
\hline $\begin{array}{l}\mathrm{T}_{3}: 50 \% \mathrm{~N} \text { through organics \& } 50 \% \mathrm{~N} \text { through in- } \\
\text { organic }\end{array}$ & 77.3 & 69.1 & 50.9 & 2.85 \\
\hline $\mathrm{T}_{4}: 100 \% \mathrm{~N}$ through in-organics and FYM @ $7 \mathrm{t} / \mathrm{ha}$ & 77.2 & 69.0 & 50.9 & 2.83 \\
\hline$T_{5}: 100 \%$ RDF, $150: 75: 75 \mathrm{~kg} / \mathrm{ha}$ & 77.2 & 68.7 & 49.9 & 2.79 \\
\hline $\operatorname{SEm} \pm$ & 0.33 & 0.43 & 0.75 & 0.04 \\
\hline CD@5\% & NS & NS & 2.33 & NS \\
\hline
\end{tabular}


Table.3 Cooking quality parameters of paddy grain as influenced by different treatments (after 11 years)

\begin{tabular}{|c|c|c|c|}
\hline Treatment & $\begin{array}{c}\text { Amylose } \\
\text { content } \\
(\%)\end{array}$ & $\begin{array}{c}\text { Elongation } \\
\text { Ratio } \\
(\%)\end{array}$ & $\begin{array}{c}\text { Gel } \\
\text { Consistency } \\
(\%)\end{array}$ \\
\hline $\mathrm{T}_{1}: 100 \% \mathrm{~N}$ through organics & 19.7 & 1.80 & 40.0 \\
\hline $\mathrm{T}_{2}: 75 \% \mathrm{~N}$ through organics & 19.1 & 1.76 & 41.7 \\
\hline $\begin{array}{l}\mathrm{T}_{3}: \mathbf{5 0} \% \mathrm{~N} \text { through organics } \& \\
50 \% \mathrm{~N} \text { through in-organic }\end{array}$ & 20.3 & 1.74 & 31.5 \\
\hline $\begin{array}{l}\mathrm{T}_{4}: 100 \% \mathrm{~N} \text { through in- } \\
\text { organics and FYM @ } 7 \mathrm{t} / \mathrm{ha}\end{array}$ & 19.0 & 1.78 & 32.7 \\
\hline $\begin{array}{l}\mathrm{T}_{5}: 100 \% \text { RDF, 150: } 75: 75 \\
\mathrm{~kg} / \mathrm{ha}\end{array}$ & 18.9 & 1.76 & 34.7 \\
\hline $\mathrm{SEm} \pm$ & 0.83 & 0.02 & 6.52 \\
\hline CD@5\% & NS & NS & NS \\
\hline
\end{tabular}

Table.4 Nutritional quality parameters of paddy grain as influenced by different treatments (after 11 years)

\begin{tabular}{|c|c|c|c|c|c|c|c|c|c|}
\hline Treatment & $\begin{array}{c}\text { Protein } \\
(\%)\end{array}$ & $\begin{array}{l}\text { Lysine } \\
\text { g per } 16 \\
\text { g N }\end{array}$ & $\begin{array}{l}\text { Tryptopha } \\
\text { n g per } 16 \\
\text { g N }\end{array}$ & $\underset{(g / k g)}{P}$ & $\underset{(g / k g)}{K}$ & $\begin{array}{c}\mathrm{Zn} \\
(\mathrm{mg} / \mathrm{kg} \\
)\end{array}$ & $\begin{array}{c}\mathrm{Fe} \\
(\mathrm{mg} / \mathrm{kg} \\
)\end{array}$ & $\begin{array}{c}\text { Mn } \\
(\mathrm{mg} / \mathrm{kg} \\
)\end{array}$ & $\begin{array}{c}\mathrm{Cu} \\
(\mathrm{mg} / \mathrm{k} \\
\mathrm{g})\end{array}$ \\
\hline $\begin{array}{l}\mathrm{T}_{1}: 100 \% \mathrm{~N} \\
\text { through organics }\end{array}$ & 7.05 & 3.67 & 1.12 & 39.4 & 34.9 & 11.3 & 16.7 & 3.02 & 3.63 \\
\hline $\begin{array}{l}\mathrm{T}_{2}: 75 \% \mathrm{~N} \\
\text { through organics }\end{array}$ & 6.84 & 3.50 & 1.09 & 32.1 & 29.3 & 10.1 & 19.3 & 2.35 & 2.47 \\
\hline $\begin{array}{l}\mathrm{T}_{3}: 50 \% \mathrm{~N} \\
\text { through organics } \\
\& 50 \% \mathrm{~N} \\
\text { through in- } \\
\text { organic }\end{array}$ & 6.58 & 3.47 & 1.15 & 33.5 & 28.1 & 11.0 & 15.9 & 3.10 & 2.67 \\
\hline $\begin{array}{l}\mathrm{T}_{4}: 100 \% \mathrm{~N} \\
\text { through in- } \\
\text { organics and } \\
\text { FYM @ } 7 \mathrm{t} / \mathrm{ha}\end{array}$ & 6.89 & 3.85 & 1.14 & 39.0 & 36.8 & 9.57 & 17.3 & 2.31 & 3.38 \\
\hline $\begin{array}{c}T_{5}: 100 \% \text { RDF, } \\
150: 75: 75 \mathrm{~kg} / \mathrm{ha}\end{array}$ & 6.87 & 3.57 & 1.07 & 28.8 & 28.8 & 10.3 & 16.1 & 2.23 & 2.30 \\
\hline SEm \pm & 0.25 & 0.18 & 0.03 & 0.94 & 1.20 & 0.72 & 0.95 & 0.32 & 0.27 \\
\hline CD@5\% & NS & NS & NS & 2.90 & 3.70 & NS & NS & NS & NS \\
\hline
\end{tabular}


Fig.1 Yield parameters of paddy as influenced by treatments

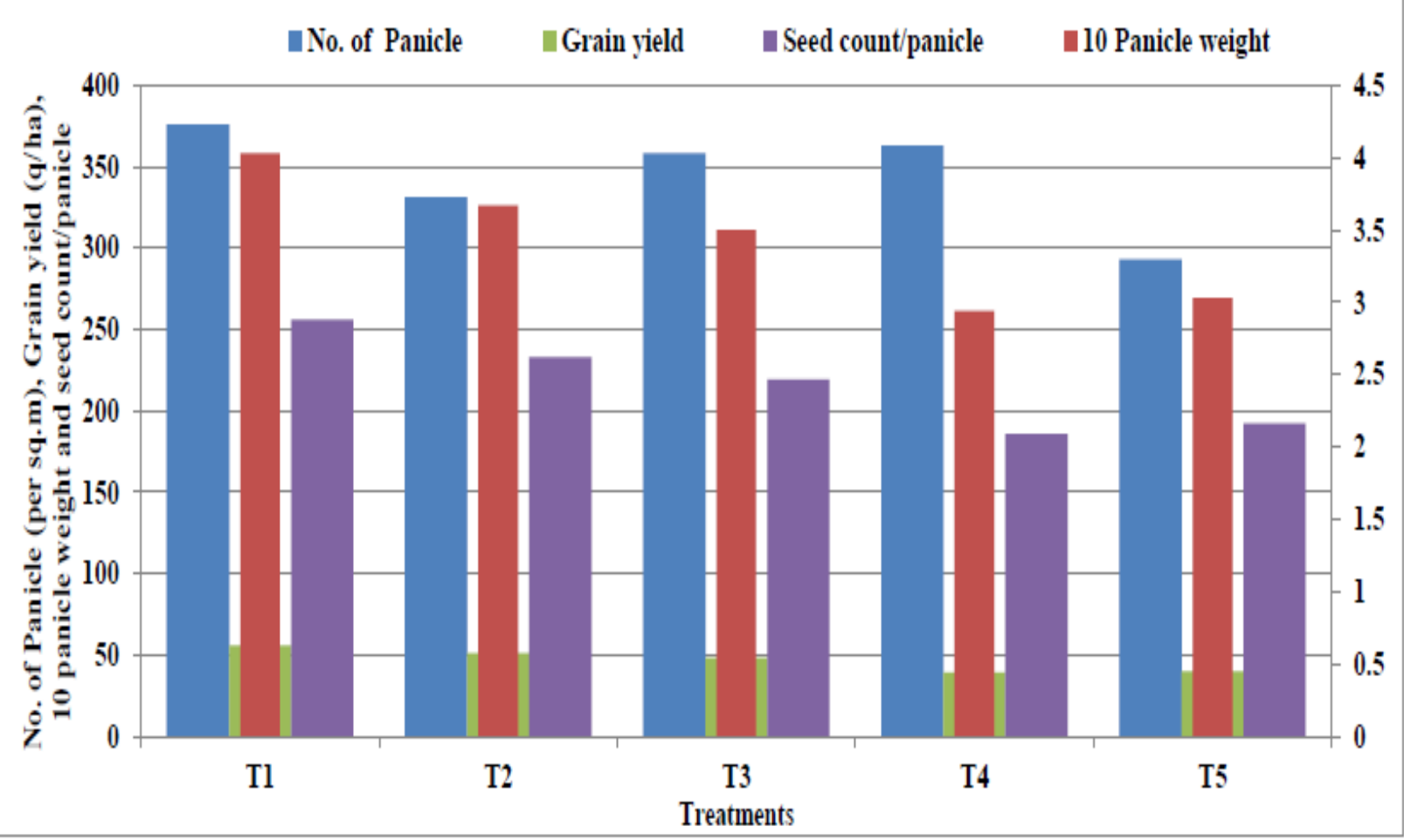

Legend:

T1: $100 \% \mathrm{~N}$ through organics

T2: $75 \% \mathrm{~N}$ through organics.

T3: Integrated $\mathrm{N}$ management $(50 \% \mathrm{~N}$ through organics \& $50 \% \mathrm{~N}$ through inorganic)

T4: $100 \% \mathrm{~N}$ through inorganics and FYM @ $7 \mathrm{t} \mathrm{ha}^{-1}$

T5: $100 \%$ RDF, 150: 75:75 $\mathrm{kg} \mathrm{ha}^{-1}$

\section{Nutritional parameters of rice grain}

Nutritional parameters such as protein, lysine, tryptophan and micronutrients namely, Zn, $\mathrm{Fe}, \mathrm{Mn}$ and $\mathrm{Cu}$ were not influenced significantly by application of organic sources of nutrients (table 4). However the content of $\mathrm{P}$ and $\mathrm{K}$ differed significantly among the treatments. Though there was a non significant difference in the content of protein, lysine and tryptophan, a marginal increase in their content was recorded due to supply of 100 per cent nitrogen through organic source compared to inorganic source. Similarly, there was a slight increase in the accumulation of $\mathrm{Zn}, \mathrm{Fe}, \mathrm{Mn}$ and $\mathrm{Cu}$ in rice grain in the treatment which received entire nitrogen through organics alone compared to in-organic source. Besides, significant increase in the content of P and K (39.4 \& $34.9 \mathrm{~g} / \mathrm{kg}$ ) was recorded due to supplement of entire nitrogen through different organic manures, whereas the treatment which received in-organic fertilizers accumulated lower $\mathrm{P}$ and $\mathrm{K}$ content in rice grain $(28.8$ \& $23.0 \mathrm{~g} / \mathrm{kg}$, respectively). These findings are in line with the findings of Surekha and Ali (2010).

\section{References}

Dixit, K. G. and Gupta, B. R., 2000, Effect of farm yard manure, chemical and biofertilizers on yield and quality of rice 
(Oryza sativa L.) and soil properties. $J$. Indian Soc. Soil Sci., 48(4): 773 - 780.

Dwivedi, D. K. and Thakur, S. S., 2000, Effect of organic and inorganic fertility levels on productivity of rice (Oryza sativa L.) crop. Indian J. Agron., 45(3): $568-574$.

Gopalasamy, G. and Vidhyasekaran, P., 1987, Effect of green leaf manure on soil fertility and rice yield. Int. Rice Newsletter, 12(2): 41.

Hemalatha, M., Thirumurugan, V. and Balasubramanian, R., 2000, Effect of organic sources of nitrogen on productivity, quality of rice (Oryza sativa $L$.) and soil fertility in single crop wet lands. Indian J. Agron., 45(3): 564 - 567.
Shukla, S., Meena, R. N., Meena, R., Verma, V.K., Ghilotia, Y. K. and Gaurav. 2016. Effects of different organic sources of nutrition on nutrient uptake, yield attributes and economics of paddy. Bangladesh J. of Botany. 45(2): 445449.

Surekha and Ali, A., 2010, Effect of farm yard manure, chemical and biofertilizers on yield and quality of rice (Oryza sativa L.) and soil properties. J. Indian Soc. Soil Sci., 48(4) : 773-780.

Thiagarajan, M., 1991, Yield maximization in rice through green manuring, plant duration and time of phosphorus application. M.Sc.(Agri.) Thesis, Tamil Nadu Agric. Univ., Coimbatore.

\section{How to cite this article:}

Praveen Karikatti, S. N. Bhat, S. R. Balanagoudar, B. G. Mastanareddy, Satyanarayana Rao and Veeresh, H. 2020. Long Term Effect of Organic, Integrated and Inorganic Nutrient Management Practices on Crop Performance and Quality Parameters of Rice (Oryza sativa L.) in a Vertisol. Int.J.Curr.Microbiol.App.Sci. 9(01): 2327-2332.

doi: https://doi.org/10.20546/ijcmas.2020.901.264 